\title{
ECOLOGICAL ASPECTS OF RED SQUIRREL (SCIURUS VULGARIS) DREYS IN CITY PARKS
}

\author{
Vitalijus Stirké \\ Laboratory of Mammalian Ecology, Nature Research Centre, Akademijos 2, 08412 Vilnius, \\ Lithuania; E-mail: vstirke@gmail.com; https://orcid.org/0000-0002-3089-5381
}

Modified habitats often pose challenges to native fauna. Red squirrels (Sciurus vulgaris) successfully inhabits territory of the cities. However research on quite abundant red squirrel populations in urban parks of Lithuania was lacking. The investigation was carried out in two city parks (area of Giruliai park 152 ha, Pasaku park forest - 31 ha) in Vilnius, Lithuania. Both areas were mainly coniferous, dominated with pine (Pinus sylvestris). Drey $(\mathrm{N}=415)$ counts were done in February and March 2014-2016. Dreys were found in eight tree species. The red squirrels' dreys were mainly built in most widespread tree species: pine $(84.8 \%$ of all dreys) and birch (8.1\%). Most of the found dreys were built on the side branches at the stem (47.7\%). $21.8 \%$ of the dreys were built on the branches further from the stem, $18.5 \%$ on the top branches and $12 \%$ in the stem fork-off. Most of the dreys were set in the southern exposition (33.9\%). Average number of red squirrels in both parks in 2014-2016 was $0.20 \pm 0.01$ squirrels/ha, the average number of dreys $-0.75 \pm 0.05$ dreys/ha. The population of urban red squirrels in Vilnius city parks can be regarded as stable and having medium abundance, which is supported by supplementary feeding.

Key words: Sciurus vulgaris, dreys, urban ecology, urban parks, habitat.

\section{INTRODUCTION}

Red squirrels (Sciurus vulgaris) occur from the British Isles in the west across the Palearctic to the island of Hokkaido, Japan (LeE \& FukUda 1999) in the east. All members of the genus Sciurus spend much of their active time in trees (WAUters \& DhONDT 1988). Red squirrels are also mainly arboreal.

Like most small mammals, inactive red squirrels use nests (dreys) (TonKIN 1983, Wauters \& Dhondt 1987). Dreys are compact ball-shaped nests built in trees that, as well as acting as diurnal refugia, also provide shelter from winter temperatures, protection from predators and for breeding females to raise their young (HACKetT \& PAgels 2003).

Changes in population density over the years and patterns of small-scale habitat use are reflected in the number of dreys, thus drey counts can be used as a crude index of squirrel numbers (Don 1985, Wauters \& Dhondt 1988). However, as one red squirrel uses several (usually 4-6) dreys, and more than one red squirrel can use a single drey, the number of dreys is not equal to the number of red squirrels (Tonkin 1983, WAUters \& DHONdT 1988). Squirrel density differs among habitats, with the highest numbers found in ma- 
ture woodland dominated by Scots pine. Intermediate densities are found in mixed forests, while the lowest are found in young pine stands (WAUTERs \& DноNDT 1988). Dreys are not built randomly with respect to their orientation around the trunk, but the majority of dreys are on the south-east, south, south-west or west side of the trunk, with few orientated towards the north or east. (Fornasari, CASAle \& Wauters 1997). Red squirrel dreys are spheri$\mathrm{cal}, 30 \mathrm{~cm}$ in diameter, rarely larger, situated close to the trunk of a tree or in a fork in the branches. Outer layers consist of twigs, sometimes with needles or leaves attached, the inner cavity $(12-16 \mathrm{~cm}$ in diameter) is lined with soft material such as moss, leaves, needles, clipped dry grass and bark. In research by TitTENSOR, 1970, the inner lining consisted of $57 \%$ grass, $19 \%$ moss, $16 \%$ needles and $8 \%$ of other materials. In surveying dreys, it is important to distinguish among red squirrel dreys and the nests of birds such as hooded crow (Corvus cornix), European magpie (Pica pica) and some predatory birds, all of which build similar nests from twigs.

In recent years, there have been a number of studies on red squirrel ecology in Europe, specifically in Belgium, Italy, Germany, Poland and the United Kingdom (WAUters et al. 2008, Amori et al. 2012, Biancardi \& GNoli 2016, Di Cerbo \& Biancardi 2013, Flaherty et al. 2012, Gurnell et al. 2004, Gurnell et al. 2011, Verbeylen et al. 2003, Reher et al. 2016, Turner et al. 2017, Kopij 2009, BABIŃSKA-WERKA \& ŻóŁW 2008). However, very little data have been collected on the biology and ecology of this species in Lithuania. No research has been carried out on the quite abundant populations of red squirrels in urban parks, nor has there been any comparative data on the differences in the ecology of red squirrels in urban parks in comparison to red squirrel populations in more natural environments (Kopis 2009).

The goal of this study was to investigate drey ecology (tree species and location of the dreys in the trees) of the red squirrel in an urbanized environment and provide estimates of population size.

\section{MATERIAL AND METHODS}

\section{Study area}

The study was carried out in two parks in Vilnius, in an area of 183 ha (Fig. 1). The two parks, Giruliai forest area (152 ha) and Pasaku park (31 ha), are both frequently used for recreation and are dominated by middle-aged (40-80 age) (94.4\%) and premature (80100 age) $(3.1 \%)$ forest stands, with only a small part mature (100-140 age). Both are mainly coniferous, dominated by Scots pine (Pinus sylvestris). There are also mixed, and deciduous forest stands, with silver birch (Betula pendula), Norway spruce (Picea abies), Norway maple (Acer platanoides), aspen (Populus tremula), pedunculate oak (Quercus robur) and willow (Salix sp.). Forest undergrowth is dominated by common hazel (Corylus avellana), rowan (Sorbus aucuparia), bird cherry (Prunus padus) and fly woodbine (Lonicera xylosteum). 


\section{Data collection and analysis}

We conducted our survey of red squirrel dreys during winter to determine the relative number of individuals, as well as habitat selection. Of the five indirect red squirrel monitoring methods frequently used - drey counts, feeding transects, hair tube surveys, visual surveys and whole maize bait (GurNell et al. 2009, 2004) - the drey count method was used for this study. This method is most suitable for urban parks research because there is good visibility of the dreys. Drey counting took place in February and March in 2014/2015/2016. At this time of year, trees are without leaves, which made it much easier to spot dreys. As in CAGNin et al. 2000, typical red squirrel dreys were searched and counted in order to establish the winter density of red squirrels and to determine the peculiarities of dreys building. All forest areas were traversed in transects every $50 \mathrm{~m}$.

All used red squirrel dreys were recorded. Unused dreys are translucent and partially destroyed (Gurnell \& Pepper 1994, Gurnell et al. 2004), such dreys were not counted. The following habitat characteristics were determined for each drey $(\mathrm{N}=415)$ found: coordinates, tree species, tree development, drey location on the tree (bifurcation of the stem, in the top branches, on the lateral branches away from the stem, on the side branches at the stem), drey orientation (according to KopIJ 2014), tree age and its characteristic (topheight, upper-layer, lower layer, undergrowth). Dreys were described once, using GPS coordinates to avoid replication.

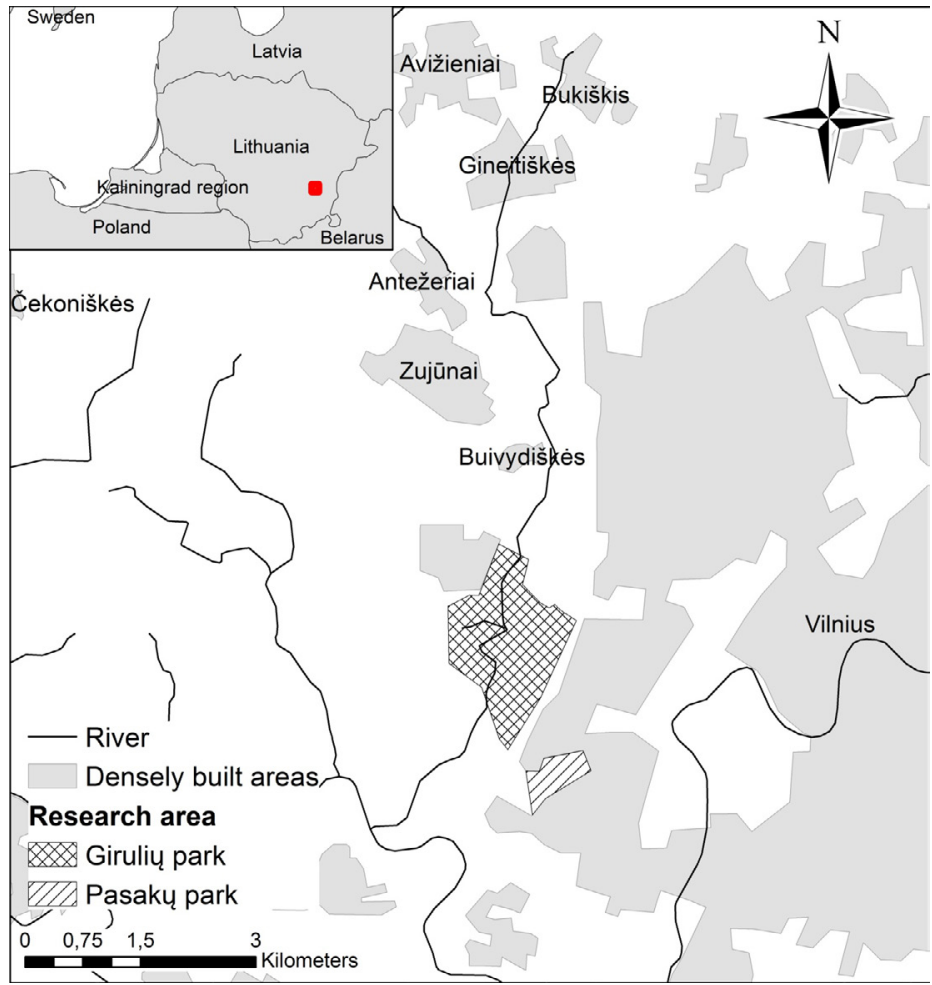

Fig. 1. Location of study areas (city parks) in Vilnius, Lithuania 
Population estimates were calculated as the number of red squirrels per ha $=$ number of dreys per ha $\times 0.26$. This equation has been validated for data from a variety of conifer and broadleaved woodlands in Belgium (WAuters \& Dhоndт 1988). Due to additional feeding, in city parks some bias may occur.

Statistica 10 software was used for the statistical processing of data. Chi-square test was used for checking variables in the sample and comparing with expected even distribution along categories in drey location in a tree, drey orientation, tree characteristic. The number of dreys and the number of squirrels among years were compared with the average number. The minimum significance level was set at $\mathrm{p}<0.05$.

\section{RESULTS}

During the three years, 415 dreys were detected in the two city parks. Most of them were found in coniferous forests (94.6\%), while $2.1 \%$ were in deciduous stands and $3.1 \%$ in mixed stands. Red squirrel dreys were found in eight tree species (Fig. 2), selection differing statistically $\left(\chi^{2}=1999.09, \mathrm{df}=7\right.$, $p=0.0001$ ). No dreys were detected in dead trees, in shrubs, in tree hollows or in man-made structures.

Most dreys were found in Scots pine, then in silver birch $(84.8 \%$ and $8.1 \%$ of the total, difference significant, $\chi^{2}=261.79, \mathrm{df}=1, \mathrm{p}=0.0001$ ). Dreys in other tree species were without significant differences $\left(\chi^{2}=6.38, \mathrm{df}=5, \mathrm{p}=0.27\right.$, Fig. $2)$. Tree were selected for dreys according to tree age $\left(\chi^{2}=349.94, \mathrm{df}=3, \mathrm{p}=\right.$ 0.0001): most of the dreys were built in middle-aged (57.8\%) and young (1-40 age) $(34.9 \%)$ trees. Premature and mature trees were represented only in a small proportion $\left(\chi^{2}=198.08, \mathrm{df}=2, \mathrm{p}=0.0001\right)$. Most of the middle-aged pine trees used for dreys were 40 to 50 years old.

Most of the dreys were detected in the top-height trees (52.9\%) and in the other upper-layer trees (24.2\%). The number of dreys was less in lower layer

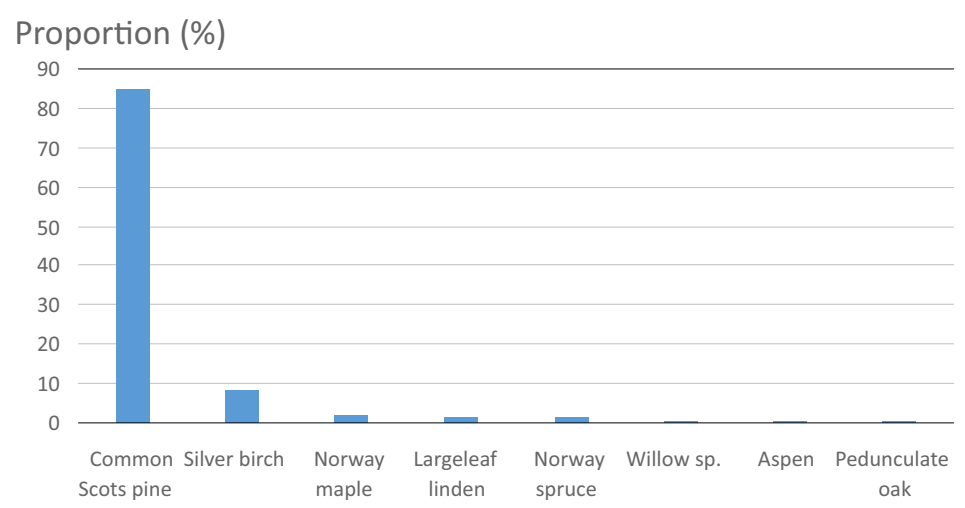

Fig. 2. Distribution of the tree species selected for the dreys $(N=415)$ of red squirrels in Vilnius city parks during 2014-2016 
Table 1. Numbers of dreys and density of the red squirrels in the city parks of Vilnius.

\begin{tabular}{lllllll}
\hline Study area & \multicolumn{3}{c}{ Number of dreys/ha } & \multicolumn{3}{c}{ Squirrels per/ha } \\
\cline { 2 - 7 } & 2014 & 2015 & 2016 & 2014 & 2015 & 2016 \\
\hline Girulių park & 0.43 & 0.51 & 0.73 & 0.11 & 0.13 & 0.18 \\
Pasaku park & 2.32 & 1.42 & 1.38 & 0.60 & 0.36 & 0.35 \\
\hline
\end{tabular}

trees, $(20 \%)$ and minimal in undergrowth trees $(2.9 \%)$. No dreys were detected in completely overshadowed trees. Tree selection for all trees was different $\left(\chi^{2}=213.96, \mathrm{df}=3, \mathrm{p}=0.0001\right)$. The choice of the lower layer and upper layer trees, as opposed to top-height ones, was equal $\left(\chi^{2}=1.58, \mathrm{df}=1, \mathrm{p}=0.21\right)$.

Drey location in the tree differed significantly $\left(\chi^{2}=121.63, \mathrm{df}=3, \mathrm{p}=\right.$ $0.0001)$. Most dreys were built on the side branches at the stem $(47.7 \%)$, while $21.8 \%$ of the dreys were built on branches further from the stem, $18.5 \%$ on the top branches and $12 \%$ in forks in the stem (Fig. 3).

Significant differences were also found concerning drey exposition/orientation $\left(\chi^{2}=98.33, \mathrm{df}=7, \mathrm{p}=0.0001\right)$. Most of the registered dreys $(33.9 \%)$ were built in the southern exposition, while other common orientations were south-eastern (13.3\%) and eastern (11\% of all dreys). Other orientations were rarely used (Fig. 4).

The average number of dreys in Giruliu park was $0.56 \pm 0.09$ dreys/ha in 2014-2016, not differing among years $\left(\chi^{2}=0.26, d f=2, p=0.88\right)$, thus the average density of red squirrels was $0.14 \pm 0.02$ squirrels/ha, difference among years not significant: $\left(\chi^{2}=0.02, d f=2, p=0.99\right)$. In Pasaku park, the average number of dreys in the same period was $1.71 \pm 0.31$ dreys/ha and the average number of red squirrels $0.44 \pm 0.08$ squirrels/ha. Neither parameters differed significantly among years $\left(\chi^{2}=0.33, \mathrm{df}=2, \mathrm{p}=0.85\right.$ and $\chi^{2}=0.09, \mathrm{df}=2, \mathrm{p}=0.96$, respectively). The dynamics of drey and red squirrel numbers are shown in the (Table 1). In the 2014-2016

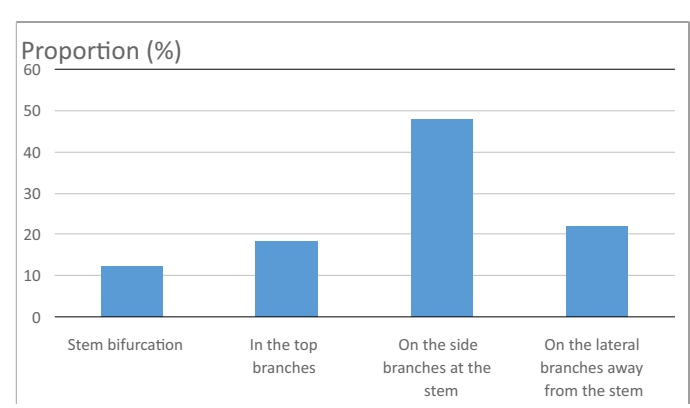

Fig. 3. Distribution of the red squirrel dreys location in Vilnius city parks $(\mathrm{N}=415)$

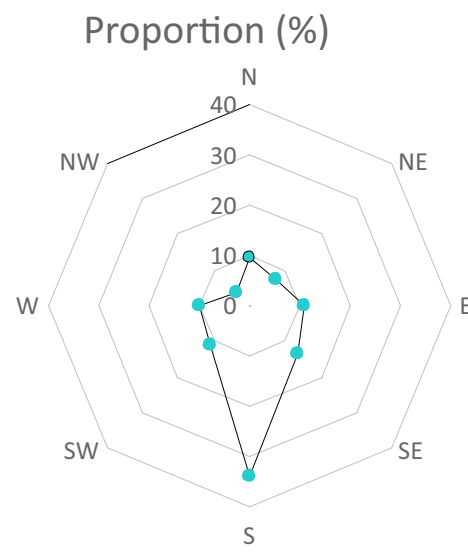

Fig. 4. Orientation of the red squirrel dreys $(\mathrm{N}=209)$ in Vilnius city parks during 2014-2016 
Table 2. Drey and red squirrel densities in Vilnius city parks (average $\pm S E$ ). Population estimates were calculated as number of red squirrels per ha $=$ number of dreys per ha $\times 0.26$.

\begin{tabular}{lcccc}
\hline Year & $\begin{array}{c}\text { Number } \\
\text { of dreys }\end{array}$ & $\begin{array}{c}\text { Number of red } \\
\text { squirrels }\end{array}$ & $\begin{array}{c}\text { Density of dreys } \\
\text { (per ha) }\end{array}$ & $\begin{array}{c}\text { Density of red } \\
\text { squirrels (per/ha) }\end{array}$ \\
\hline 2014 & 138 & 35 & 0.75 & 0.20 \\
2015 & 123 & 31 & 0.67 & 0.17 \\
2016 & 154 & 39 & 0.84 & 0.22 \\
\hline Average & $138.3 \pm 9.0$ & $35.0 \pm 2.3$ & $0.75 \pm 0.05$ & $0.20 \pm 0.01$ \\
\hline
\end{tabular}

period, on average in both parks, the average number of dreys was $0.75 \pm 0.05$ dreys/ha, and the density of red squirrels was $0.20 \pm 0.01$ squirrels/ha (Table 2 ). Differences of drey density and squirrel density were not significant among years $\left(\chi^{2}=3.47, \mathrm{df}=2, \mathrm{p}=0.18\right.$ and $\chi^{2}=0.88, \mathrm{df}=2, \mathrm{p}=0.64$ respectively). Thus, red squirrel populations in both Vilnius city parks were considered stable.

\section{DISCUSSION}

European red squirrels readily use urban parks and gardens, as well as small woods and copses (Magris \& GuRnell 2002). Research in the British Isles found that the average long-term red squirrel density ranged from 0.5 and 1.5 squirrels/ha (WAUTERs \& LeNs 1995), while in coniferous forest of Scandinavia it ranged from 0.2 to 2.0 squirrels/ha (ANDREN \& LeMNELL 1992). However, marked year-to-year fluctuations caused by weather conditions and seed abundance are known in these regions (Lurz et al. 2005). In 2015, the precipitation amount in Lithuania was higher than in 2014 (Department 2018), which possibly explains the drop in population size in this park between 2014 and 2015. As Pasaku park is used for recreation, possibly additional feeding of squirrels in it also decreased due to the decreased number of visitors in rainy weather. Additional feeding may not allow full comparison of the squirrel densities in the parks and natural woodlands in Lithuania.

Data on red squirrel population density in urban areas from the parks in Warsaw show a red squirrel density from 0.4 to 1.8 ind./ha (BABIŃsKA-WERKA \& ŻóŁw 2008), while the average red squirrel density in parks in south-west Poland was 0.3 ind./ha (Kopis 2014). In Vilnius, the average red squirrel density was 0.20 ind./ha in parks (see Table 2). The slightly higher red squirrel density observed in Pasaku park was 0.44 ind./ha. Similar results were from Parco Groane and Pineta, northern Italy, with a minimum estimate of 0.18 and a maximum of 0.60 ind./ha (ForNASARI et al. 1997).

In city parks, the tree species most often chosen by red squirrels for dreys sites were also the prevalent ones within the squirrel areas (KopIJ 2009). The Scots pine, which provides stable food (seeds) were the dominant tree species 
in most red squirrel areas. Norway maple, pedunculate oak, largeleaf linden and, especially, Norway spruce may also supply food, but they are relatively uncommon in these city parks. Therefore only a few dreys were found in these trees. In Great Britain and Belgium, most dreys are located in pines and spruces (LuRz et al. 2005, WAUTERs \& DHONDT 1988), obviously because forests are composed almost exclusively of these tree species. However, in northern Italy, in woodlands dominated both by oaks $(32 \%)$ and pines $(25 \%)$, with an admixture of black locust, birch, hornbeam and chestnuts, red squirrels also strongly prefer pine trees for drey location (ForNASARI et al. 1997). In south Italy, red squirrels selected Calabrian black pines and oaks for drey building, while other tree species, especially beech, were avoided (CAGNIN et al. 2000). In Vilnius city parks Common Scots pine was absolutely prevailing, with a limited admixture of Silver birch trees. Other tree species were very scarce. Thus, selection of tree species for dreys was not biased. It reflected stand composition - most dreys were built in the dominating tree species.

Trees must be sufficiently mature to produce a reasonable and regular food crop. Immature trees would be unlikely to hold resident squirrels. Maturity was based on the age at which the species produces a first good crop, approximately 30 years for Norway spruce and around 25 for Scots pine (GuRNELL et al. 2009). In Vilnius city parks, drey selection was influenced by tree age, as the dominant were middle-aged trees.

In Vilnius city parks, most registered red squirrel dreys were built on side branches at the stem. Similar results were obtained in northern Italy. In Parco Groane and Pineta, $84.5 \%$ of dreys were located against the main trunk and $15.5 \%$ on branches (ForNASARI et al. 1997); in the Lombardy region, the dreys were mainly built among the trunk and one main branch or in the higher part of the canopy (Biancardi \& GNoli 2016). Nesting high up in the trees is a possible adaptation to predator presence. Among natural enemies, only goshawk Accipiter gentilis, beech marten Martes foina and common buzzard Buteo buteo occasionally occur in urban parks of Vilnius (personal observation). In urbanized habitats, feral cats are regarded as the most important predator of red squirrels, with dogs, foxes, martens, stoats, buzzards, goshawks, and owls much lesser extent (Lurz et al. 2005). Probably, for this reason, dreys in Vilnius were not located in shrubs, which commonly occur in some parks (KopI 2009).

Dreys in a southern exposure could aid the squirrels' energetics and thermoregulation as they do not enter torpor to save energy (TuRner et al. 2017). In the Lombardy region, southern exposures (South-Southeast-SouthSouthwest) for the dreys were generally preferred (BIANCARDI \& GNOLI 2016). In northeastern Lapland, dreys $(\mathrm{n}=56)$ on trunks were predominantly on south-east, south and south-west sides (Pulliainen 1973). Pulliainen (1973) argued that south to west orientated dreys in Finnish Lapland were sheltered from the cold northern or eastern winds, giving a more favourable micro- 
climate around the drey. The position and orientation of dreys propose that squirrels select those places on the tree with the most favourable microclimate (Pulliainen 1973). The data obtained during the study in Vilnius showed that most dreys were oriented southward.

Feeding red squirrels is a widespread behaviour of people in Vilnius parks, frequently seen in our work. In our study site, mostly in Pasaku park, additional feeding could likely support a population with a higher density of individuals than in a natural habitat and ensure year-round food availability (e.g. ReHer et al. 2016). However, the negative effects on the number of red squirrels are also possible. In parks where red squirrels (females) are abundantly fed, they stop reproducing due to excessive density. Red squirrel feeding can also contribute to the spread of diseases and parasites (LuRz et al. 2005).

In conclusion, the population of urban red squirrels in Vilnius city parks can be regarded as stable and having medium abundance, which is supported by supplementary feeding. Most of the dreys in the parks were located in Scots pine, the prevalent tree species, providing the most stable cover and natural food. Preference for locating dreys in a southern exposure provides a favourable microclimate around the drey.

\section{MANAGEMENT RECOMMENDATIONS}

All old and hollow trees should be preserved while thinning city parks. Undergrowth should be saved to improve the food basis for red squirrels. Erecting special nestboxes is recommended to improve the availability of nesting places.

Acknowledgements - I thank Linas Balčiauskas for comments on the early draft of this paper, Justas Dainys for assistance with GIS and map design, and Romualdas Varanauskas for help in statistical analyses. I also thank the reviewers for improving this manuscript. Special thanks are extended to Gabija Juščiūtè-Stirkè for her assistance in the fieldwork.

\section{REFERENCES}

Amori, G., Mortelliti, A., Guidarelli, G., Schiavano, A. \& Luiselli, L. (2012): Detectability of the European red squirrel (Sciurus vulgaris) in a Mediterranean area. - Rendiconti Lincei 23(2): 203-206. https://doi.org/10.1007/s12210-011-0157-x

Andrén, H. \& Lemnell, P. A. (1992): Population fluctuations and habitat selection in the Eurasian red squirrel Sciurus vulgaris. - Ecography 15(3): 303-307. https://doi.org/10 .1111/j.1600-0587.1992.tb00039.x

BABıŃSKA-Werka, J. \& ŻóŁw, M. (2008): Urban populations of the red squirrel (Sciurus vulgaris) in Warsaw. - Annales Zoologici Fennici 45(4): 270-276. https://doi.org/10.5735 /086.045.0405 
Biancardi, C. M. \& Gnoli, C. G. (2016): A review of Sciurus group studies on the red squirrel (Sciurus vulgaris): presence, population density and colour phases in Lombardy (Italy). - Natural History Sciences 3(2): 27-34. https://doi.org/10.4081/nhs.2016.287

Cagnin, M., Aloise, G., Fiore, F., Oriolo, V. \& Wauters, L. A. (2000): Habitat use and population density of the red squirrel, Sciurus vulgaris meridionalis, in the Sila Grande mountain range (Calabria, South Italy). - Italian Journal of Zoology 67(1): 81-87. https:// doi.org/10.1080/11250000009356299

Di Cerbo, A. R. \& Biancardi, C. M. (2013): Monitoring small and arboreal mammals by camera traps: effectiveness and applications. - Acta Theriologica 58(3): 279-283. https://doi.org/10.1007/s13364-012-0122-9

Don, B. A. C. (1985): The use of drey counts to estimate grey squirrel populations. - Journal of Zoology 206(2): 282-286. https://doi.org/10.1111/j.1469-7998.1985.tb05656.x

Flaherty, S., Patenaude, G., Close, A. \& Lurz, P. W. W. (2012): The impact of forest stand structure on red squirrel habitat use. - Forestry: An International Journal of Forest Research 85(3): 437-444. https://doi.org/10.1093/forestry/cps042

Fornasari, L., Casale, P. \& Wauters, L. (1997): Red squirrel conservation: the assessment of a reintroduction experiment. - Italian Journal of Zoology 64(2): 163-167. https://doi .org/10.1080/11250009709356190

Gurnell, J. \& Pepper, H. (1994): Red squirrel conservation: field study methods. - Forestry Commission Research Information Note 255. Edinburgh: Forestry Commission.

Gurnell, J., Lurz, P., McDonald, R. \& Pepper, H. (2009): Practical techniques for surveying and monitoring squirrels. - Forestry Commission. Practice Note 11. Forestry Commission, Edinburgh.

Gurnell, J., Lurz, P. W. W., Shirley, M. D. F., Cartmel, S., Garson, P. J., Magris, L. \& Steele, J. (2004): Monitoring red squirrels Sciurus vulgaris and grey squirrels Sciurus carolinensis in Britain. - Mammal Review 34(1-2): 51-74. https://doi.org/10.1046/j.0305 -1838.2003.00028.x

Gurnell, J., McDonald, R. \& Lurz, P. W. (2011): Making red squirrels more visible: the use of baited visual counts to monitor populations. - Mammal Review 41(3): 244-250. https://doi.org/10.1111/j.1365-2907.2010.00174.x

Hackett, H. M. \& Pagels, J. F. (2003): Nest site characteristics of the endangered northern flying squirrel (Glaucomys sabrinus coloratus) in southwest Virginia. - The American Midland Naturalist 150(2): 321-331. https://doi.org/10.1674/0003-0031(2003)150[0321: nscote]2.0.co;2

KopIJ, G. (2009): Habitat and drey sites of the red squirrel Sciurus vulgaris Linnaeus, 1758 in suburban parks of Wrocław, SW Poland. - Acta Zoologica Cracoviensia-Series A: Vertebrata 52(1-2): 107-114. https://doi.org/10.3409/azc.52a_1-2.107-114

KopIJ, G. (2014): Distribution and abundance of the Red Squirrel Sciurus vulgaris in an urbanised environment. - Acta Musei Silesiae, Scientiae Naturales 63(3): 255-262. https:// doi.org/10.2478/cszma-2014-0022

LeE, T. H. \& FukudA, H. (1999): The distribution and habitat use of the Eurasian red squirrel Sciurus vulgaris L. during summer, in Nopporo Forest Park, Hokkaido. - Mammal Study 24(1): 7-15. https://doi.org/10.3106/mammalstudy.24.7

Lurz, P. W., Gurnell, J. \& Magris, L. (2005): Sciurus vulgaris. Mammalian Species 769: 1-10. MAgris, L. \& GuRnell, J. (2002): Population ecology of the red squirrel (Sciurus vulgaris) in a fragmented woodland ecosystem on the Island of Jersey, Channel Islands. - Journal of Zoology 256(1): 99-112. https://doi.org/10.1017/s0952836902000134

Pulliainen, E. (1973): Winter ecology of the red squirrel (Sciurus vulgaris L.) in northeastern Lapland. - Annales Zoologici Fennici 10(4): 487-494. 
Reher, S., Dausmann, K. H., Warnecke, L. \& Turner, J. M. (2016): Food availability affects habitat use of Eurasian red squirrels (Sciurus vulgaris) in a semi-urban environment. - Journal of Mammalogy 97(6): 1543-1554. https://doi.org/10.1093/jmammal/gyw105

Tittensor, A. M. (1970): Red squirrel dreys. - Journal of Zoology 162(4): 528-533. https://doi .org/10.1111/j.1469-7998.1970.tb01290.x

TonkIN, J. M. (1983): Activity patterns of the red squirrel (Sciurus vulgaris). - Mammal Review 13(2-4): 99-111. https://doi.org/10.1111/j.1365-2907.1983.tb00271.x

Turner, J. M., Reher, S., Warnecke, L. \& Dausmann, K. H. (2017): Eurasian red squirrels show little seasonal variation in metabolism in food-enriched habitat. - Physiological and Biochemical Zoology 90(6): 655-662. https://doi.org/10.1086/694847

Verbeylen, G., De Bruyn, L., Adriaensen, F. \& Matthysen, E. (2003): Does matrix resistance influence Red squirrel (Sciurus vulgaris L., 1758) distribution in an urban landscape? - Landscape Ecology 18(8): 791-805. https://doi.org/10.1023/b:land.0000014492 .50765 .05

Wauters, L. A. \& Dhondt, A. A. (1988): The use of red squirrel Sciurus vulgaris dreys to estimate population density. - Journal of Zoology 214(1): 179-187. https://doi.org/10 .1111/j.1469-7998.1988.tb04995.x

Wauters, L. A. \& Dhondt, A. A. (1990): Nest-use by red squirrels (Sciurus vulgaris Linnaeus, 1758). - Mammalia 54(3): 377-390. https://doi.org/10.1515/mamm.1990.54.3.377

Wauters, L. A. \& Dhondt, A. A. (1987): Activity budget and foraging behaviour of the red squirrel (Sciurus vulgaris, Linnaeus, 1758) in a coniferous habitat. - Zeitschrift für Säugetierkunde 52(6): 341-353. https://doi.org/10.1111/j.1469-7998.1992.tb04345.x

Wauters, L. A., Githiru, M., Bertolino, S., Molinari, A., Tosi, G. \& Lens, L. (2008): Demography of alpine red squirrel populations in relation to fluctuations in seed crop size. - Ecography 31(1): 104-114. https://doi.org/10.1111/j.2007.0906-7590.05251.x

Wauters, L. A. \& Lens, L. (1995): Effects of food availability and density on red squirrel (Sciurus vulgaris) reproduction. - Ecology 76(8): 2460-2469. https://doi.org/10.2307 $/ 2265820$

Department of Hydrology and Climatology (2018): Aggregated data. http://www.hkk. gf.vu.lt/vu_ms/duomenu-suvestine/ (accessed 2018 September 25)

Received May 3, 2018, accepted February 9, 2019, published March 18, 2019 